\title{
PENGARUH MODEL PEMBELAJARAN MEA DENGAN METODE SCAFFOLDING TERHADAP PENGUASAAN KONSEP FISIKA DITINJAU DARI SRL
}

\author{
Petronela Agata Moong, Chandra Sundaygara, Hena Dian Ayu \\ Program Studi Pendidikan Fisika, Universitas Kanjuruhan Malang \\ Email: chandrakirana@unikama.ac.id
}

Diterima: 3 September 2019 Disetujui: 17 Maret 2020

\begin{abstract}
Abstrak
Penelitian ini bertujuan untuk mengetahui pengaruh model pembelajaran MEA dengan metode scaffolding terhadap penguasaan konsep fisika ditinjau dari SRL. Metode penelitian ini adalah quasy experimental dengan rancangan posttest only control group design. Penentuan sampel dengan teknik purposive sampling dengan instrumen penelitian adalah soal tes dan angket. Uji hipotesis menggunakan uji anova dua jalur pada taraf signifikan 5\% dengan bantuan program Microsoft Excel 2010. Hasil analisis diketahui bahwa pembelajaran menggunakan MEA dengan metode scaffolding berbeda dengan konvensional. Hal ini dibuktikan dari uji anova dua jalur penguasaan konsep fisika menunjukkan $\mathrm{F}_{\text {Hitung }}>\mathrm{F}_{\text {Tabel }}(4,2>3,92)$. Uji anova dua jalur penguasaan konsep fisika berdasarkan SRL tinggi dan rendah menunjukkan $\mathrm{F}_{\text {Hitung }}>\mathrm{F}_{\text {Tabel }}(26,17>3,92)$, artinya penguasaan konsep siswa yang memiliki SRL tinggi berbeda dengan siswa yang memiliki SRL rendah. Dapat disimpulkan bahwa model pembelajaran MEA dengan metode scaffolding berpengaruh terhadap penguasaan konsep fisika ditinjau dari SRL.

Kata Kunci: : MEA, scaffolding, penguasaan konsep, SRL.
\end{abstract}

\begin{abstract}
This study aims to determine the effect of the MEA learning model with the scaffolding method on the mastery of physics concepts in terms of SRL. This research method is quasi-experimental with the posttest only control group design. The determination of the sample with a purposive sampling technique with research instruments is a matter of tests and questionnaires. Hypothesis testing uses the two-way ANOVA test at a significant level of 5\% with the help of the Microsoft Excel 2010 program. The results of the analysis note that learning using MEA with different scaffolding methods with conventional. This is evidenced by the ANOVA two-path mastery of physics concepts showing $F_{\text {count }}>F_{\text {Tabel }}(4.2>3.92)$. ANOVA test results on the two concepts of mastery of physics-based on high and low SRL showed $F_{\text {count }}>F_{\text {Table }}(26.17>3.92)$, meaning that the concept of mastery of students who have high SRL is different from students who have low SRL. It can be concluded that the MEA learning model with the scaffolding method affects the mastery of physics concepts in terms of SRL.
\end{abstract}

Keywords: MEA, scaffolding, Mastery of Concept, SRL 


\section{PENDAHULUAN}

Pada kenyataannya fisika merupakan salah satu pembelajaran yang kurang disukai dan menakutkan (Suryani \& Fatkhulloh, 2012) karena dianggap sulit dan membosankan (Samudra et al., 2014). Perlu kita sadari bahwa proses pembelajaran fisika merupakan proses yang harus menitik beratkan pada pembentukan konsep. Untuk dapat membentuk konsep yang benar terhadap pelajaran fisika peserta didik harus diarahkan pada pembelajaran yang memberikan peserta didik pengalaman untuk langsung menemukan konsep tersebut (Suparmin, 2017). Pembelajaran berdasarkan pengalaman memberikan peserta didik seperangkat/ serangkaian situasi atau keadaan belajar yang dimana terdapat keterlibatan pengalaman yang nyata yang dirancang sedemikian rupa oleh guru (Minati, 2017). Untuk mengatasi permasalahan dalam pembelajaran dibutuhkan suatu model pembelajaran yang dapat menyelesaikan permasalahan pada pembelajaran fisika untuk mengembangkan kemampuan berpikir siswa dalam proses pembelajaran yaitu model pembelajaran

Means-Ends

Analysis(MEA).

MEA adalah variasi dari pembelajaran dengan pemecahan masalah (Shoimin, 2014). MEA merupakan model untuk menganalisis permasalahan melalui berbagai cara untuk mencapai tujuan akhir yang diinginkan (Huda, 2013). Pada model pembelajaran MEA peserta didik dituntut untuk mengetahui apa tujuan yang hendak dicapai didalam proses pembelajaran dan bagaimana memecahkan suatu masalah yang disajikan kedalam sub-sub yang lebih sederhana dan kemudian dikerjakan serta mencari solusi dalam pemecahan masalah sehingga mencapai tujuan dari pembelajaran (Sari, 2018). Pemecahan masalah yang baik akan berdampak pada penguasaan konsep yang baik (Sundaygara, 2014). Hasil penelitian sebelumnya menunjukkan bahwa penguasaan konsep siswa meningkat setelah diterapkan model pembelajaran MEA (Maindra et al., 2013; Hartini, 2015). Akan tetapi MEA memiliki kekurangan yaitu mengemukakan masalah yang langsung dapat dipahami siswa sangat 
Moong., Sundaygara., Ayu. - Pengaruh Model Pembelajaran MEA ...

sulit sehingga banyak siswa yang mengalami kesulitan bagaimana merespon masalah yang diberikan (Shoimin, 2014).

Salah satu metode yang dapat mengatasi kesulitan merespon masalah pada model pembelajaran MEA adalah metode scaffolding. Koes (2012) mengatakanscaffolding merupakan pendampingan kognitif yang berhubungan dengan Zona of Proximal Development (ZPD) bahwa pembelajaran terjadi apabila siswa bekerja atau belajar menangani tugastugas atau masalah kompleks yang masih berada pada jangkauan kognitif siswa atau tugas-tugas tersebut berada padaZPD. Scaffolding merupakan bantuan kepada siswa secara terstruktur pada awal pembelajaran dan kemudian secara bertahap mengaktifkan siswa untuk belajar mandiri (Melinda, 2015).Penelitian sebelumnya menunjukkan bahwa bahwa metode scaffolding mampu meningkatkan penguasaan konsep fisika siswa (Apriana, 2014; Herman, 2015).

Selain model dan metode pembelajaran, faktor lain yang mempengaruhi penguasaan konsep siswa adalah Self Regulated Learning (SRL). SRL adalah kemampuan seorang peserta didik mengarahkan dirinya sendiri (Schunk dan Zimmerman, 1998), mengendalikan pikiran, perilaku, dan emosinya untuk mencapai kesuksesan di dalam proses belajar (Zumbrunn, Taddlock dan Roberts 2011).

\section{METODE}

Rancangan yang digunakan dalam penelitian ini adalahposttest only control group designdapat dilihat pada tabel 1. Teknik pemilihan sampel menggunakan teknik purposive sampling dengan instrumen penelitian adalah soal tes obyektif untuk mengukur penguasaan konsep fisika siswa dan angket untuk mengukur SRL siswa.

Tabel 1.Desain Penelitian Posttest only control group design

\begin{tabular}{lcc}
\hline \multicolumn{1}{c}{ Kelas } & Perlakuan & Posttest \\
\hline Eksperimen & $X_{1}$ & $T_{1}$ \\
Kontrol & $X_{2}$ & $T_{2}$ \\
\hline
\end{tabular}


Keterangan :

$X_{1}$ : Pemberian perlakuan (treatment) kepada kelas eksperimen menggunakan model MEA dengan metode schaffolding

$X_{2}$ : Pemberian perlakuan (treatment) kepada kelas kontrol menggunakan model konvensional

$T_{1}$ : posttest penguasaan konsep kelas eksperimen

$T_{2}$ : Posttest penguasaan konsep kelas control

Teknik analisis data meliputi uji prasyarat (uji normalitas dan uji homogenitas) dan uji hipotesis. Uji hipotesis menggunakan uji anova dua jalur dengan bantuan Microsoft Excel 2010.

Rumus uji hipotesis:

$F_{\text {hitung }}=\frac{K R}{K R D}$

$K R=\frac{J K}{d b} \operatorname{dan} K R D=\frac{J K D}{d b}$
HASIL DAN PEMBAHASAN

Langkah awal dalam proses analisis dat adalah melakukan uji normalitas dan homogenitas dari sampel yang dipilih. Setelah data yang diuji normal dan homogen maka selanjutnya dilakukan uji hipotesis menggunakan uji anova dua jalur. Hasil uji anova dua jalur dapat dilihat pada tabel 2 .

Tabel 2. Hasil Uji Hipotesis Anova 2 Jalur

\begin{tabular}{lcc}
\hline \multicolumn{1}{c}{ Hipotesis } & $\mathbf{F}_{\text {hitung }}$ & $\mathbf{F}_{\text {tabel }}$ \\
\hline Model Pembelajaran & 4,2 & 3,92 \\
SRL & 26,17 & 3,92 \\
Model Pembelajaran * SRL & 4,08 & 3,92 \\
\hline
\end{tabular}

Tabel 2 menunjukkan bahwa ada perbedaan antara model pembelajaran MEA dengan metode scaffolding dan model pembelajaran konvensional terhadap penguasaan konsep fisika. Hal ini dibuktikan dengan hasil analisis yaitu $\mathrm{F}_{\text {Hitung }}>$ $\mathrm{F}_{\text {Tabel }}(4,2>3.92)$ pada taraf signifikansi 0,05 . Siswa yang mengalami kesulitan dalam menguasai konsep, peneliti memberikan bantuan berupa pertanyaan, arahan, memberikan contoh dan tindakan-tindakan lain yang memungkinkan siswa belajar mandiri. bantuan seperti ini disebut 
scaffolding (Taylor dalam Sugiatno, 2010).Penggunaan model pembelajaran MEA dengan metode scaffolding dapat merangsang siswa untuk aktif dalam kegiatan pembelajaran dimana guru dapat mengambil langkah-langkah yang tepat untuk menyesuaikan kemampuan siswa dalam pemberian materi serta contoh-contoh riil yang berkaitan dengan materi tersebut sehingga pengetahuan siswa yang didapatkan akan sesuai dengan tahap perkembangannya. Oleh karena itu, siswa dituntut untuk terlibat secara aktif dalam memecahkan masalah agar mampu mencapai semua indikator pembelajaran yang terdapat pada setiap fase pembelajaran dengan kemampuan berpikir lebih tinggi. Aktivitas belajar dengan adanya penggunaan model ini dapat mempermudah siswa dalam menguasai materi dan siswa tidak cepat merasa bosan dalam mengikuti proses pembelajaran (Arinata et al., 2017). Model pembelajaran MEA dengan metode scaffolding mampu meningkatkan penguasaan konsep fisika siswa dengan optimal. Hal ini sesuai dengan pendapat Slavin dalam
(Isjoni, 2009) yang menyatakan bahwa dalam melakukan proses belajar mengajar guru tidak lagi mendominasi seperti lazimnya saat ini, sehingga siswa dituntut untuk berbagi informasi dengan siswa lainnya dan saling belajar mengajar sesama mereka.

Tabel 2 menunjukkan bahwa ada perbedaan antara siswa yang memiliki SRL tinggi dengan siswa yang memiliki SRL rendah terhadap penguasaan konsep Fisika. Hal ini dibuktikan dengan hasil analisis yaitu $\mathrm{F}_{\text {Hitung }}>\mathrm{F}_{\text {Tabel }}(26,17>3,92)$ pada taraf signifikansi 0,05 . Siswa yang memiliki SRL tinggi memiliki motivasi yang baik dan memiliki banyak waktu untuk belajar seperti mengatur jadwal jam belajar di rumah, membagi jam belajar saat ada tugas sekolah. Sedangkan siswa yang memiliki SRL rendah kurang memiliki motivasi dan waktu yang digunakan untuk belajar juga kurang.

Hal ini juga menunjukkan bahwa SRL penting khususnya dalam bentuk pengarahan diri dalam belajar seperti mencari informasi sendiri dari berbagai sumber dan belajar sosial seperti mencari bantuan dari teman, 
orangtua dan guru (Tekeng, 2015). Hal ini sejalan dengan hasil penelitian yang dilakukan oleh Fasikhah (2013) yang menujukkan bahwa SRL berpengaruh terhadap hasil prestasi akademik. menunjukkan bahwa model pembelajaran MEA dengan scaffolding memiliki kaitan erat dengan SRL. Dengan demikian, penguasaan konsep fisika siswa dengan SRL tinggi cenderung lebih tinggi daripada siswa dengan SRL rendah.

\section{KESIMPULAN DAN SARAN}

\section{Kesimpulan}

Siswa dengan SRL tinggi yang mengikuti pembelajaran MEA dengan metode scaffolding cenderung belajar lebih baik, mengatur belajarnya secara efektif, mengatur dan mengarahkan diri sendiri untuk mencapai hasil terbaik dalam belajar. Hal ini dibuktikan dengan hasil penelitian bahwa ada perbedaan penguasaan konsep fisika antara siswa yang memiliki SRL tinggi dan siswa yang memiliki SRL rendah. Hasil penelitian ini juga menunjukkan bahwa model pembelajaran MEA dengan metode scaffolding berpengaruh terhadap penguasaan konsep fisika ditinjau dari SRL.

\section{Saran}

Dalam menerapkan model MEA guru harus mampu mengemukakan masalah yang langsung dipahami siswa, karena banyak siswa yang mengalami kesulitan bagaimana merespon masalah yang diberikan.Dalam menerapkan metode scaffolding guru harus kreatif dalam memberikan kata kunci, petunjuk ataupun isyarat sehingga siswa merasa tertarik untuk terlibat aktif dalam pembelajaran.

\section{DAFTAR PUSTAKA}

Apriana, A., Maharta, N., \& Abdurrahman, A. (2014). Pengaruh Scaffolding Dalam Pemecahan Masalah Fisika Berbasis Multirepresentasi Terhadap Hasil Belajar Siswa. Jurnal Pembelajaran Fisika, 2(1). http://jurnal.fkip.unila.ac.id/index. php/JPF/article/view/3725

Arinata, A. C. D., Suniasih, N. W., \& Darsana, I. W. (2017). Pengaruh Model Problem Based Learning Berbasis Penilaian Kinerja Terhadap Kompetensi Pengetahuan IPA Siswa Kelas IV SD Gugus Kapten Kompyang Sujana Kecamatan Denpasar Barat Tahun Pelajaran 2016/2017. MIMBAR PGSD Undiksha, 5(2). 
Moong., Sundaygara., Ayu. - Pengaruh Model Pembelajaran MEA ...

https://ejournal.undiksha.ac.id/inde

x/php/JJPGSD/article/download/10 $\underline{832 / 6934}$

Fasikhah, S.S., \& Fatimah, S. (2013).

Self-Regulated Learning (SRL)

Dalam Meningkatkan Prestasi Akademik Pada Mahasiswa. Jurnal Ilmiah Psikologi Terapan, 1 (1), 145-155.

http://ejournal.umm.ac.id/index.ph p/jipt/article/download/1364/1459

Hartini, T. I., \& Lianti, M. (2015). Pengaruh Penerapan Model Pembelajaran Means End Analysis (MEA) Terhadap Hasil Belajar Fisika. Jurnal Fisika dan Pendidikan Fisika. 1 (1), 20-23. http://omega.uhamka.ac.id/index.p $\mathrm{hp} / \mathrm{jk} / \mathrm{article} / \mathrm{view} / 13 / 28$

Herman, J., \& Handayani S.M. (2015). Pengaruh Model Pembelajaran Gi Dengan Scaffolding Terhadap Penguasaan Konsep Fisika. Jurnal Pemikiran Penelitian dan Sains, 3 (6), 159169.

Huda, M. (2013). Model-model Pengajaran dan Pembelajaran. Yogyakarta: Pustaka Pelajar

Isjoni. (2009). Pembelajaran Kooperatif Meningkatkan Kecerdasan Komunikasi Antar Peserta Didik. Yogyakarta: Pustaka Pelajar.

Koes, H.S. (2012). Pengaruh Strategi Scaffolding-Kooperatif dan Pengetahuan Awal Terhadap Prestasi Belajar dan Sikap pada Matakuliah Fisika Dasar. Universitas Negeri Malang: Disertasi tidak diterbitkan.

Maindra, K., Sudirtha, I. G., \& Wahyuni, D. S. (2013). Penerapan
Model Pembelajaran Kooperatif Tipe Means Ends Analysis (MEA) Untuk Meningkatkan Aktivitas Dan Hasil Belajar Siswa Mata Pelajaran TIK Kelas XII IPA 2 SMA Negeri 1 Kubutambahan Tahun Pelajaran 2012/2013. KARMAPATI (Kumpulan Artikel Mahasiswa Pendidikan Teknik Informatika), 2(6), 709-713.

Minati, D. F. (2017). Pengaruh Pembelajaran Berdasarkan Pengalaman (Experiental Learning) Terhadap Pengetahuan Prosedural Fisika Ditinjau Dari Gaya Belajar Peserta Didik Kelas $\mathrm{X}$ MA DDI Takkalasi Barru. Jurnal Pendidikan Fisika-Journal of Physics Education, 5(1), 1-14.

Melinda, M., Sugiatno, S., \& Hamdani, H. (2015). Strategi Scaffolding Berbasis Multirepresentasi untuk Mengatasi Kesulitan Pemahaman Konseptual Siswa dalam Operasi Pecahan di SMP. Jurnal Pendidikan dan Pembelajaran Untan, 4(1), 1-10. http://jurnal.untan.ac.id/index.php/j pdpb/article/view/8773/8733

Sari, Y. N. (2018). Pengaruh Penerapan Model Pembelajaran Means Ends Analysis Menggunakan Media Video Terhadap Keaktifan Belajar Peserta Didik Pada Mata Pelajaran Ekonomi Di SMA Negeri 3 Pagar Alam. Jurnal PROFIT Kajian Pendidikan Ekonomi dan Ilmu Ekonomi, 5(1), 89-103.

Samudra, G. B., Suastra, I. W., \& Suma, K. (2014). Permasalahanpermasalahan yang dihadapi siswa SMA di kota singaraja dalam mempelajari fisika. Jurnal 
Moong., Sundaygara., Ayu. - Pengaruh Model Pembelajaran MEA ...

Pendidikan dan Pembelajaran IPA

Indonesia, 4(1).

http://oldpasca.undiksha.ac.id

Schunk, D.H., Zimmerman, B.J (Eds). $\quad$ 1998. Self-regulated learning: From teaching to selfreflective practice. New York, NY, US: Guilford Press.

Shoimin, A. (2014). 68 Model Pembelajaran Inovatid dalam Kurikulum 2013. Yogyakarta: ArRuzz Media.

Sugiatno, S. (2010). Model Sajian Verbal-Model-Abstrak dan ModelVerbal-Abstrak untuk Materi Penjumlahan dan Pengurangan Pecahan di Sekolah Menengah Pertama. Jurnal Cakrawala Kependidikan, 8 (2), 182-189.

Sundaygara, C., Kusairi, S., \& Hidayat, A. (2014). Pengaruh Multi Representasi pada Pembelajaran Berbasis Masalah terhadap Kemampuan Representasi Siswa SMA. Jurnal FOTON, Jurnal Fisika dan Pembelajaran, 18 (2).
Suparmin, S. (2017). Penerapan Model Pembelajaran Berpikir Induktif Dalam Pembelajaran Fisika Pada Peserta Didik Kelas X SMA Negeri 16 Makassar. Jurnal Pendidikan Fisika-Journal of Physics Education, 5(1), 75-89.

https://www.neliti.com/journals/jur nal-pendidikan-fisika-unismuh

Suryani, F., \& Fatkhulloh.(2012). Peningkatan Kreativitas Siswa dalam Proses Belajar Fisika pada Konsep Gelombang Elektromagnet Melalui Pembelajaran Think, Write, and Talk. Prossiding Pertemuan Ilmiah XXVI HFI Jateng \& DIY,Purworejo, 187-190.

Tekeng, St. N. Y. (2015). Belajar Berdasar Regulasi Diri dalam Pembelajaran di Perguruan Tinggi. Lentera Pendidikan, 18 (1), 82-94. Zumbrunn, S., Tadlock, J., \& Roberts, E.D. (2011). Encouraging SelfRegulated Learning in the Classroom: a Review of the Literature. Metropolitan Educational Research Consortium (MERC), Virginia Commonwealth University. 